\title{
Effect of feed form, pellet diameter and enzymes supplementation on carcass characteristics, meat quality, blood plasma constituents and stress indicators of broilers
}

\author{
Youssef A. Attia', Walid S. El-Tahawy², Abd El-Hamid E. Abd El-Hamid², Antonino \\ Nizza $^{3}$, Mohammed A. Al-Harthi' ${ }^{1}$ Mahmoud I. El-Kelway ${ }^{4}$ and Fulvia Bovera ${ }^{3}$ \\ ${ }^{1}$ Arid Land Agriculture Department, Faculty of Meteorology, Environment and Arid Land Agriculture, King Abdulaziz \\ University, Jeddah, Saudi Arabia, ${ }^{2}$ Department of Animal and Poultry Production, Faculty of Agriculture, Damanhour \\ University, Damanhour, Egypt, ${ }^{3}$ Department of Veterinary Medicine and Animal Science, University of Napoli Federico \\ II, Italy, ${ }^{4}$ Department of Animal and Poultry Production, Faculty of Agriculture (New Valley), Assiut University, Egypt
}

\begin{abstract}
Four hundred-twenty broilers were used in a factorial design $(4 \times 3)$ in which four feed forms (mash vs. pellet diet with diameter of $2 \mathrm{~mm}, 3 \mathrm{~mm}$ and $3.5 \mathrm{~mm}$, respectively) and three enzymes treatments (unsupplemented, phytase, phytase+multi-enzyme) were used. Each treatment was replicated five times (7 broiler/replicate). Feed form had no effects on most of carcass traits and physical characteristics of meat, but pellet diets decreased the relative weight of gizzard and caecum length. Feeding $3.5 \mathrm{~mm}$ pellet diets increased abdominal fat compared to that of broilers fed mash diets. Pellet with $3 \mathrm{~mm}$ diameter increased and decreased respectively meat fat and moisture. Pellets with $3.5 \mathrm{~mm}$ diameter increased meat ash compared to broilers fed mash diet. Levels of plasma glucose and alanine aminotransferase of broilers fed $2 \mathrm{~mm}$ pellet, cholesterol of broilers fed $3 \mathrm{~mm}$ pellet and albumin/globulin ratio, monocytes and red blood cells of broilers fed $3.5 \mathrm{~mm}$ pellet were significantly higher than those of broilers fed mash diet. Haemoglobin, phagocytic activity, heterophils and heterophils/lymphocyte ratio were higher in groups fed mash diets and $2 \mathrm{~mm}$ pellet. Packed cell volume and phagocytic index were the highest in group fed mash diets. Phytase or multienzyme+phytase increased carcass yield, total edible parts and decreased inedible parts compared to broilers fed diet without enzyme supplementation. Enzyme supplementations significantly and similarly increased plasma glucose, total protein, triglycerides, red blood cells and phagocytic activity and decreased phagocytic index in comparison to the control
\end{abstract}

Archiv Tierzucht 57 (2014) 30, 1-14

Received: 3 April 2014

doi: 10.7482/0003-9438-57-030

Accepted: 17 July 2014

Corresponding author:

Online: 14 November 2014

Fulvia Bovera; email: bovera@unina.it

Department of Veterinary Medicine and Animal Science, University of Napoli Federico II, Via delpino 1, 80145 Napoli, Italy

(c) 2014 by the authors; licensee Leibniz Institute for Farm Animal Biology (FBN), Dummerstorf, Germany.

This is an Open Access article distributed under the terms and conditions of the Creative Commons Attribution 3.0 License

(http://creativecommons.org/licenses/by/3.0/). 
group. However, phytase alone decreased cholesterol and increased monocytes by contrast with the control group. Multi-enzymes+phytase induced greater effect on white blood cells than phytase alone.

Keywords: broilers, feed form, multi-enzymes, phytase, blood parameters, carcass characteristics, meat quality

Abbreviations: ALT: alanine aminotransferase; AST: aspartate aminotransferase; $\mathrm{H} / \mathrm{L}$ ratio: heterophils/lymphocyte ratio; PA: phagocytic activity; PCV: packed cell volume; PI: phagocytic index; RBC: red blood cells; WBC: white blood cells

\section{Introduction}

The physical forms of diets and feed particle size have a great effect on poultry yield (Amerah et al. 2007). Agunbiade (2000) and Adeyemi et al. (2008) reported that higher percentage of dressing, breast meat, drumstick and thigh, which are the most expensive commercial cuts of the chicken, were obtained in birds fed pelleted diets. Hassan \& El-Sheikh (2010) showed that both carcass and giblets percentages were not affected by feed form, while gizzard percentage and digestive tract weight decreased in groups fed pellets in comparison to mash diets. Also, Twina et al. (1994) found that the relative weight of the gizzard was reduced by pellet. Several authors also found an effect of feed form (mash or pellet) on some blood parameters as total protein, albumin, serum ALT and aspartate aminotransferase (AST) (Andi et al. 2011, Corzo et al. 2012).

The use of phytase or enzyme cocktails containing phytase can further improve broilers' performance. Ismail et al. (2006) found that enzyme cocktails significantly decreased intestinal percentage, while no significantly effects on carcass yields and internal organs percentage (proventriculus, gizzard, liver and heart) of broilers were observed. The relative weight of the breast, legs, liver, and gizzard as percentage of live weight were unaffected by enzyme supplementations (Shirzadi et al. 2009). Similar results were found for carcass yield, which was higher in enzyme supplemented broilers (Abudabos 2010, 2012). Kidd et al. (2001) and Attia et al. $(2003 a, b)$ found that multi-enzymes and phytase had no effects on carcass yields and internal organs of broilers. Biochemical constituents of blood plasma including plasma total protein with their fractions, plasma total lipids, cholesterol and liver enzymes (AST and ALT) were not affected by enzymes (Al-Harthi, 2006). Also, Qota et al. (2002) found that cell-wall degrading enzymes and/or phytase supplementation had no adverse effect on biochemical constituents of plasma and liver function of broilers. Abudabos (2012) reported that serum total protein, calcium and phosphorus were affected by enzymes.

The aim of this work was to investigate the effect of feed form (mash vs. pellet), pellet diameter $(2,3$ and $3.5 \mathrm{~mm}$ ) and enzyme supplementation (phytase vs. an enzyme cocktail containing xylanase, amylase, subtilisin and phytase) on carcass characteristics, meat quality, blood plasma constituents and stress indicators of broilers from 21 to $37 \mathrm{~d}$ of age. 


\section{Material and methods}

\section{Experimental design}

A total of 420 twenty-one day old Arbor acres broilers were randomly distributed among 60 cages (seven birds per cage). The cages were equally divided into four groups (15 cages per group) and broilers were submitted to the following dietary treatments up to $37 \mathrm{~d}$ of age (grower period 21-29d, finisher period 30-37 d). The groups fed, respectively: mash diet; pellet diet with $2 \mathrm{~mm}$ diameter in both grower and finisher periods; pellet diet with $2 \mathrm{~mm}$ diameter in grower and $3 \mathrm{~mm}$ diameter in finisher period; pellet diet with $3 \mathrm{~mm}$ diameter in grower and $3.5 \mathrm{~mm}$ diameter in finisher period. Each group was divided into three subgroups (five cages/ subgroups) whose diets were unsupplemented (control subgroups) or supplemented with phytase, Phyzyme XP $(0.07 \mathrm{~g} / \mathrm{kg}$ diet $)$ or multi-enzyme containing Avizyme $1505(0.2 \mathrm{~g} / \mathrm{kg}$ diet) plus Phyzyme XP $\left(0.07 \mathrm{~g} / \mathrm{kg}\right.$ diet). Pelleting temperature did not exceed $80^{\circ} \mathrm{C}$. Phyzyme and Avizyme are products of Danisco Animal Nutrition (Marlborough, Wiltshire, UK). Avizyme 1505 is a multi-enzyme containing $1500 \mathrm{U} / \mathrm{g}$ endo- $1,4-\beta$-xylanase, $2000 \mathrm{U} / \mathrm{g}$ a-amylase and $20000 \mathrm{U} / \mathrm{g}$ subtilisin. Phyzyme XP is an Escherichia coli phytase classified as a 6-phytase with hydrolysis of the phosphate moiety being initiated at the 6-position on the phytate molecule. The feeding system and husbandry practice during 1-20 $\mathrm{d}$ of age are presented by Attia et al. (2012).

The experimental diets were formulated according to NRC (1994). Chemical analysis of diets was according to AOAC (2004). Ingredients and chemical composition of the diets (as fed basis) fed during the grower and finisher periods are shown in Table 1. The available $P$ (avP) and Ca contents were adjusted in the diets supplemented with phytase according to phytase equivalent values (Attia 2003a, b, Attia et al. 2003a, Choct 2006).

\section{Housing and husbandry}

Broilers were housed in battery brooders in semi-opened house. Each cage $(60 \mathrm{~L} \times 45 \mathrm{~W} \times 35 \mathrm{H})$ was equipped with $60 \mathrm{~cm}$ type feeders and one nipple drinker. Broilers were fed ad libitum the experimental diets and given free access to water. A light schedule was $20 \mathrm{~h}$ light during 21 st to 34 th $\mathrm{d}$ of age followed by $24 \mathrm{~h}$ of light until slaughter. The average outdoor minimum and maximum temperature and relative humidity during the experimental period were 21.2 and $24.2^{\circ} \mathrm{C}$ and 56.7 and $58.7 \%$, respectively. The housing temperature was $24^{\circ} \mathrm{C}$ at $21 \mathrm{~d}$ of age, declined gradually to $21^{\circ} \mathrm{C}$ at $28 \mathrm{~d}$ of age and was then stabilized until slaughter. Chicks were vaccinated against most common diseases such as Newcastle disease, avian influenza, infectious bursa disease and infectious bronchitis.

\section{Slaughter test}

At $37 \mathrm{~d}$ of age, six broilers (three of each sex) were taken randomly from each treatment and slaughtered. The remaining carcass after bleeding, plucking and eviscerating was weighed (dressing percentage), divided into breast and hind parts and weighed. Liver, gizzard, heart and spleen were separated and individually weighed. The carcass parts were expressed as relative to live body weight. The edible parts included the empty carcass plus giblets (liver, gizzard and heart), while inedible parts included feather, blood, head, digestive tract and 
spleen. A sample of breast meat and thigh meat (50:50 basis) was analysed for dry matter, protein, fat and ash according to AOAC (2004). Meat tenderness was measured according to the method of Volovinskaia and Kelman (1962). Colour intensity of meat was determined according to the method of Husani et al. (1950).

Table 1

Ingredients and chemical composition of the experimental diets

\begin{tabular}{|c|c|c|c|c|c|c|}
\hline & \multicolumn{3}{|c|}{ Grower diets (21-29d) } & \multicolumn{3}{|c|}{ Finisher diets $(30-37 d)$} \\
\hline & Without & Multi-Enzymes & Phytase & Without & Multi-Enzymes & Phytase \\
\hline \multicolumn{7}{|l|}{ Ingredients, g/kg } \\
\hline Maize & 518.5 & 518.5 & 518.5 & 560.0 & 560.0 & 560.0 \\
\hline Soybean meal (44\%) & 244.2 & 244.2 & 244.2 & 280.0 & 280.0 & 280.0 \\
\hline Full fat soybean meal & 130.0 & 130.0 & 130.0 & 0.0 & 0.0 & 0.0 \\
\hline Rye & 50.0 & 50.0 & 50.0 & 70.0 & 70.0 & 70.0 \\
\hline Vegetable oil blend & 20.0 & 20.0 & 20.0 & 53.0 & 53.0 & 53.0 \\
\hline Dicalcium Phosphate & 16.0 & 11.0 & 5.50 & 16.0 & 11.0 & 5.50 \\
\hline Limestone & 10.0 & 10.0 & 10.0 & 10.0 & 10.0 & 10.0 \\
\hline $\mathrm{NaCl}$ & 4.5 & 4.5 & 4.5 & 4.5 & 4.5 & 4.5 \\
\hline Vit+min premix ${ }^{1}$ & 3.0 & 3.0 & 3.0 & 3.0 & 3.0 & 3.0 \\
\hline DL-Methionine & 2.0 & 2.0 & 2.0 & 2.0 & 2.0 & 2.0 \\
\hline L-Lysine & 1.5 & 1.5 & 1.5 & 1.5 & 1.5 & 1.5 \\
\hline Washed building sand & 0.30 & 5.03 & 10.73 & 0.0 & 4.73 & 10.43 \\
\hline Avizyme 1505 & 0.0 & 0.2 & 0.0 & 0.0 & 0.2 & 0.0 \\
\hline Phyzyme $x^{2}$ & 0.0 & 0.07 & 0.07 & 0.0 & 0.07 & 0.07 \\
\hline \multicolumn{7}{|c|}{ Determined ${ }^{*}$ and calculated ${ }^{* *}$ chemical-nutritional composition, $\mathrm{g} / \mathrm{kg}$} \\
\hline Dry matter* & 875.5 & 875.0 & 876.1 & 870.0 & 870.3 & 870.6 \\
\hline $\mathrm{ME}, \mathrm{MJ} / \mathrm{kg}^{* *}$ & 12.98 & 12.98 & 12.98 & 13.38 & 13.38 & 13.38 \\
\hline $\mathrm{CP}, \% *$ & 211.2 & 211.0 & 211.4 & 185.3 & 185.5 & 185.0 \\
\hline Crude fat, \%* & 64.5 & 64.3 & 64.7 & 68.0 & 68.3 & 67.8 \\
\hline Crude fibre, $\% *$ & 35.1 & 35.3 & 34.9 & 38.0 & 38.2 & 38.3 \\
\hline Ash, \%* & 54.8 & 54.8 & 54.8 & 57.0 & 57.0 & 57.0 \\
\hline Lysine, $\%^{* *}$ & 12.3 & 12.3 & 12.3 & 10.4 & 10.4 & 10.4 \\
\hline Methionine, \%** & 5.2 & 5.2 & 5.2 & 4.8 & 4.8 & 4.8 \\
\hline Meth+cystine ${ }^{* *}$ & 8.7 & 8.7 & 8.7 & 7.8 & 7.8 & 7.8 \\
\hline Calcium ${ }^{* *}$ & 8.5 & 7.4 & 6.4 & 8.3 & 7.2 & 6.2 \\
\hline Total P** & 5.8 & 4.9 & 3.9 & 5.3 & 5.3 & 4.3 \\
\hline Average $P^{* *}$ & 4.1 & 3.2 & 3.2 & 4.1 & 3.2 & 3.2 \\
\hline $\mathrm{NFE}, \%^{* *}$ & 634.4 & 634.4 & 634.4 & 651.7 & 651.7 & 651.7 \\
\hline
\end{tabular}

'Vit+Min mix provides per kilogram of the diet: Vit. A, $12000 \mathrm{IU}$, vit. E (dl-a-tocopheryl acetate) $20 \mathrm{mg}$, menadione $2.3 \mathrm{mg}$, Vit. D3, $2200 \mathrm{ICU}$, riboflavin $5.5 \mathrm{mg}$, calcium pantothenate $12 \mathrm{mg}$, nicotinic acid $50 \mathrm{mg}$, Choline $250 \mathrm{mg}$, vit. B12 $10 \mathrm{mg}$, vit. B6 $3 \mathrm{mg}$, thiamine $3 \mathrm{mg}$, folic acid $1 \mathrm{mg}$, d-biotin $0.05 \mathrm{mg}, \mathrm{Mn} 80 \mathrm{mg}$, Zn $60 \mathrm{mg}$, Fe $35 \mathrm{mg}$, Cu $8 \mathrm{mg}$, Selenium $0.1 \mathrm{mg}$. ${ }^{2}$ Calcium and phosphorus of the phytase supplemented-diet were adjusted according to phytase equivalent value.

\section{Haematological and biochemical characteristics}

Blood samples were collected in heparinized tubes from six birds per treatment at $37 \mathrm{~d}$ of age. Plasma was separated by centrifugation at $3000 \mathrm{rpm}$ for $10 \mathrm{~min}$ and stored at $-18^{\circ} \mathrm{C}$ until analysis. All biochemical traits of blood plasma (total protein, albumin, total cholesterol triglycerides, glucose and ALT) were determined using commercial diagnosing kits (Diamond Diagnostics Company, Egypt) as reported by Attia et al. (2009, 2011a and b). Globulin 
concentration was calculated as the difference of total protein - albumin. Ten blood samples per treatment were collected to determine haemoglobin, RBC, white blood cells (WBC), different types of leukocytes, haemoglobin concentration, packed cell volume (PCV) and phagocytic activity and index according to Attia et al. (2013).

\section{Statistical analyses}

Data were processed using the general linear model (GLM) procedure of SAS v9 (SAS Institute Inc., Cary, NC, USA) by a two-way factorial design (four types of feed form by three enzymes treatments and their interaction). Mean difference at $P \leq 0.05$ was tested using StudentNewman-Keuls-test. All percentages were transformed to their corresponding arcsin value before run the analyses.

\section{Results}

\section{Carcass traits}

The carcass and body organs characteristics of broilers as affected by form of diet and enzyme supplementation are shown in Table 2 . The body weight at slaughter was higher $(P<0.01)$ in broilers fed pellet in comparison to mash diet. Pellet diets resulted in lower $(P<0.0001)$ relative weight of gizzard than mash diets. However, percentage of abdominal fat of broilers fed the 3-3.5 mm pellet diet was higher $(P<0.005)$ than that of broilers fed mash and $2-2 \mathrm{~mm}$ pellet diet. The percentage of abdominal fat in broilers fed $2-3 \mathrm{~mm}$ pellet was not different than that of the other groups. Furthermore, percentage of caecum length of groups fed $3-3.5 \mathrm{~mm}$ pellet diet was significantly lower than that of broilers fed the mash diet. The caecum length of birds fed $2-2$ and $2-3 \mathrm{~mm}$ pellet was between the other two groups.

Table 2

Relative weight of carcass characteristics and body organs of $37 \mathrm{~d}$ old broilers as affected feed form and enzymes supplementations

\begin{tabular}{|c|c|c|c|c|c|c|c|c|}
\hline Treatment & $\begin{array}{c}\text { Body weight, } \\
\mathrm{g}\end{array}$ & $\begin{array}{c}\text { Carcas, } \\
\text { g }\end{array}$ & $\begin{array}{c}\text { Dressing, } \\
\%\end{array}$ & $\begin{array}{c}\text { TEP, } \\
\%\end{array}$ & $\begin{array}{l}\text { IP, } \\
\%\end{array}$ & $\begin{array}{c}\text { Gizzard, } \\
\%\end{array}$ & $\begin{array}{l}\text { Abdominal } \\
\text { fat, } \%\end{array}$ & $\begin{array}{l}\text { Caecum } \\
\text { length, } \%\end{array}$ \\
\hline \multicolumn{9}{|l|}{ Feed form } \\
\hline Mash & $1780^{\mathrm{b}}$ & $1277^{b}$ & 71.8 & 75.9 & 24.1 & $1.40^{\mathrm{a}}$ & $0.657^{\mathrm{b}}$ & $1.139^{\mathrm{a}}$ \\
\hline Pellet 2-2 mm & $1968^{\mathrm{a}}$ & $1429^{a}$ & 72.9 & 76.7 & 23.3 & $1.10^{\mathrm{b}}$ & $0.653^{b}$ & $1.028^{\mathrm{ab}}$ \\
\hline Pellet 2-3 mm & $2001^{\mathrm{a}}$ & $1463^{\mathrm{a}}$ & 73.1 & 77.0 & 23.0 & $1.08^{\mathrm{b}}$ & $0.823^{\mathrm{ab}}$ & $1.025^{\mathrm{ab}}$ \\
\hline Pellet 3-3.5 mm & $1992^{\mathrm{a}}$ & $1481^{\mathrm{a}}$ & 74.4 & 78.4 & 21.6 & $1.18^{\mathrm{b}}$ & $1.014^{\mathrm{a}}$ & $0.977^{b}$ \\
\hline \multicolumn{9}{|l|}{ Enzymes supplementation } \\
\hline Control & 1940 & 1395 & $71.9^{b}$ & $75.7^{\mathrm{b}}$ & $24.3^{\mathrm{a}}$ & 1.19 & 0.850 & 1.05 \\
\hline Phytase & 1945 & 1416 & $72.7^{\mathrm{ab}}$ & $76.7^{\mathrm{ab}}$ & $23.3^{\mathrm{ab}}$ & 1.21 & 0.762 & 1.02 \\
\hline Multi-enzyme+phytase & 1922 & 1427 & $74.6^{\mathrm{a}}$ & $78.6^{\mathrm{a}}$ & $21.4^{\mathrm{b}}$ & 1.17 & 0.748 & 1.06 \\
\hline SEM & 30.2 & 24.6 & 1.52 & 1.58 & 1.58 & 0.077 & 0.135 & 0.059 \\
\hline \multicolumn{9}{|l|}{$P$-value } \\
\hline Feed form & 0.004 & 0.000 & 01 ns & ns & ns & 0.0001 & 0.005 & 0.013 \\
\hline Enzymes suppl. & ns & ns & 0.046 & 0.042 & 0.042 & ns & ns & ns \\
\hline Interaction & ns & ns & ns & ns & ns & ns & ns & ns \\
\hline
\end{tabular}

$a, b, c$ Means in the same column followed by different letters are significantly different at $P \leq 0.05$; ns: not significant; SEM: standard error of mean, TEP: total edible parts, IP: inedible parts 
The group fed diets supplemented with multi-enzyme+phytase showed greater $(P<0.05)$ carcass yield and total edible and lower total inedible parts than the control groups. Groups supplemented with phytase exhibited intermediate values. There was no significant influence of the interaction for all the criteria reported in Table 2.

\section{Meat quality}

The chemical and physical characteristics of broiler meat affected by feed form and enzyme supplementation are shown in Table 3. The meat moisture was significantly lower in broilers fed 2-3 mm pellet than that of the groups fed mash diet or 3-3.5 mm pellet. Meat lipid of broilers fed 2-2 and 2-3 mm pellet diets was significantly higher than that of broilers fed mash and 3-3.5 mm pellet diet. However, meat ash was significantly higher in broilers fed $2-3 \mathrm{~mm}$ and $3-3.5 \mathrm{~mm}$ pellet diet than that of those fed $2-2 \mathrm{~mm}$ pellet. There was no effect of feed form on protein as well as on physical characteristics of meat.

Table 3

Chemical composition and physical characteristics of fresh meat of $37 \mathrm{~d}$ old broiler as affected feed form and enzymes supplementation

\begin{tabular}{|c|c|c|c|c|c|c|}
\hline & \multicolumn{4}{|c|}{ Chemical composition of meat, $\%$} & \multicolumn{2}{|c|}{ Physical characteristics of meat } \\
\hline & Moisture & Protein & Lipid & Ash & Colour & Tenderness \\
\hline \multicolumn{7}{|l|}{ Feed form: } \\
\hline Mash & $68.6^{\mathrm{a}}$ & 22.5 & $5.06^{b}$ & $3.90^{\mathrm{ab}}$ & 0.193 & 2.73 \\
\hline Pellet 2-2mm & $66.9^{\mathrm{ab}}$ & 23.1 & $6.36^{\mathrm{a}}$ & $3.60^{\mathrm{b}}$ & 0.201 & 2.74 \\
\hline Pellet 2-3mm & $65.8^{\mathrm{b}}$ & 23.8 & $6.35^{\mathrm{a}}$ & $4.01^{\mathrm{a}}$ & 0.214 & 2.82 \\
\hline Pellet 3-3.5mm & $68.3^{\mathrm{a}}$ & 22.2 & $5.34^{b}$ & $4.20^{\mathrm{a}}$ & 0.184 & 2.75 \\
\hline \multicolumn{7}{|l|}{ Enzymes supplementation } \\
\hline Control & $68.6^{a}$ & $22.1^{\mathrm{b}}$ & 5.60 & 3.73 & 0.188 & 2.74 \\
\hline Phytase & $67.2^{\mathrm{b}}$ & $22.9^{\mathrm{ab}}$ & 5.75 & 4.07 & 0.208 & 2.8 \\
\hline Multi-enzyme+phytase & $66.3^{b}$ & $23.7^{\mathrm{a}}$ & 5.99 & 3.98 & 0.198 & 2.73 \\
\hline \multicolumn{7}{|l|}{$P$-value } \\
\hline Feed form & 0.014 & ns & 0.0002 & 0.026 & ns & ns \\
\hline Enzymes & 0.002 & 0.005 & ns & ns & ns & ns \\
\hline Interaction & 0.0001 & 0.019 & 0.0001 & ns & ns & 0.009 \\
\hline Standard error of mean & 1.19 & 0.99 & 0.40 & 0.42 & 0.015 & 0.065 \\
\hline
\end{tabular}

$\mathrm{a}, \mathrm{b}, \mathrm{c}$ Means in the same column followed by different letters are significantly different at $P \leq 0.05$, ns: not significant

Phytase+multi-enzyme resulted in significantly lower meat moisture than the unsupplemented control but, phytase+multi-enzyme significantly induced higher meat protein than unsupplemented diet. Phytase supplemented group showed intermediate meat protein. There was no significant influence of enzyme supplementations on meat lipid and ash and meat physical characteristics.

A significant interaction of feed formxenzyme supplementations was shown for meat moisture, protein and lipid percentages and meat tenderness. In the control group higher levels of meat moisture were recorded with mash and 3-3.5 mm pellet diet. When the broilers' diets were supplemented with phytase, there were similar moisture contents for mash, 2-3 mm and 3-3.5 $\mathrm{mm}$ pellet diet but higher values were observed for the other diet. The groups fed phytase and multi-enzymes showed no differences in meat moisture. The 
level of meat protein was lower in the control groups when broilers fed mash and 3-3.5 mm pellet diet, while no difference was observed for 2-2 diet. With 2-3 mm pellet diet, a lower value of meat protein was recorded with phytase supplementation. The amount of lipids was lower in the control group than in the phytase or multi-enzyme groups when mash and 3-3.5 mm diets were fed. The opposite occurred with 2-2 $\mathrm{mm}$ pellet diet. For meat tenderness the group fed 2-3 $\mathrm{mm}$ pellet diet+phytase showed the highest value, while no differences were observed among the other groups.

\section{Biochemical constituents of plasma}

The plasma biochemical constituents of broilers are shown in Table 4. Albumin/globulin ratio was higher $(P<0.05)$ in broilers fed 3-3.5 mm pellet diet than in those fed $2-3 \mathrm{~mm}$ pellet. Cholesterol was higher $(P<0.01)$ in $2-3 \mathrm{~mm}$ pellet diet than that in the others. Broilers fed $2-2 \mathrm{~mm}$ and $2-3 \mathrm{~mm}$ pellet diet showed higher $(P<0.05)$ plasma glucose than those fed mash diets. Plasma ALT was higher $(P<0.01)$ in broilers fed $2-2 \mathrm{~mm}$ pellet diet than only that in those fed 3-3.5 $\mathrm{mm}$ pellet.

Table 4

Biochemical constituents of blood serum of $37-d$ old broilers as affected feed form and enzymes supplementation

\begin{tabular}{|c|c|c|c|c|c|c|c|c|}
\hline Treatment & $\begin{array}{c}\mathrm{TP} \\
\mathrm{g} / 100 \mathrm{ml}\end{array}$ & $\begin{array}{c}\text { Alb } \\
\mathrm{g} / 100 \mathrm{ml}\end{array}$ & Alb/Glob & $\begin{array}{c}\text { Glu } \\
\mathrm{mg} / \mathrm{dl}\end{array}$ & $\begin{array}{l}\text { Trigl } \\
\mathrm{mg} / \mathrm{dl} \mathrm{n}\end{array}$ & $\begin{array}{c}\text { Chol } \\
\mathrm{mg} / 100 \mathrm{ml}\end{array}$ & $\begin{array}{l}\text { ALT } \\
\mathrm{U} / \mathrm{I}\end{array}$ & AST/ALT \\
\hline \multicolumn{9}{|l|}{ Feed form } \\
\hline Mash & 4.68 & 2.63 & $1.32^{\mathrm{ab}}$ & $77.2^{\mathrm{b}}$ & 187 & $202^{b}$ & $69.9^{\mathrm{ab}}$ & 0.895 \\
\hline Pellet 2-2 mm & 4.97 & 2.69 & $1.24^{\mathrm{ab}}$ & $82.1^{\mathrm{a}}$ & 190 & $190^{\mathrm{b}}$ & $72.5^{\mathrm{a}}$ & 0.862 \\
\hline Pellet 2-3 mm & 5.06 & 2.54 & $1.05^{\mathrm{b}}$ & $81.7^{\mathrm{a}}$ & 189 & $208^{\mathrm{a}}$ & $70.5^{\mathrm{ab}}$ & 0.878 \\
\hline Pellet 3-3.5 mm & 4.89 & 2.79 & $1.54^{\mathrm{a}}$ & $80.3^{\mathrm{ab}}$ & 191 & $204^{b}$ & $68.3^{b}$ & 0.929 \\
\hline \multicolumn{9}{|l|}{ Enzymes } \\
\hline Control & $4.70^{\mathrm{b}}$ & 2.62 & 1.35 & $76.4^{\mathrm{b}}$ & $186^{b}$ & $206^{\mathrm{a}}$ & 66.9 & 0.899 \\
\hline Phytase & $5.03^{\mathrm{a}}$ & 2.66 & 1.20 & $82.5^{\mathrm{a}}$ & $191^{\mathrm{a}}$ & $192^{\mathrm{b}}$ & 70.8 & 0.884 \\
\hline Multi-enzyme+phytase & $4.98^{\mathrm{a}}$ & 2.72 & 1.31 & $82.2^{\mathrm{a}}$ & $191^{\mathrm{a}}$ & $206^{\mathrm{a}}$ & 70.5 & 0.889 \\
\hline \multicolumn{9}{|l|}{$P$-value } \\
\hline Feed form & ns & ns & 0.044 & 0.041 & ns & 0.003 & 0.003 & ns \\
\hline Enzymes & 0.048 & ns & ns & 0.003 & 0.025 & 0.002 & ns & ns \\
\hline Interaction & ns & 0.009 & ns & ns & ns & 0.01 & 0.0001 & 0.007 \\
\hline Standard error of mean & 0.19 & 0.14 & 0.20 & 2.25 & 2.48 & 1.77 & 1.23 & 0.03 \\
\hline
\end{tabular}

$\mathrm{a}, \mathrm{b}, \mathrm{c}$ Means in the same column followed by different letters are significantly different at $P \leq 0.05$, ns: not significant, TP: total protein, Alb: albumin, Glob: globulin, Glu: glucose, Trigl: triglycerides, Chol: cholesterol

Enzyme supplementations resulted in higher total protein $(P<0.05)$, plasma glucose $(P<0.01)$ and triglycerides $(P<0.05)$ than the control group but phytase alone decreased $(P<0.01)$ cholesterol compared to the other groups.

A significant interaction diet form $x$ enzymes supplementation was shown only on plasma albumin, cholesterol, ALT and ALT/AST ratio. The level of albumin was quite similar among groups when 2-3 and 3-3.5 $\mathrm{mm}$ pellet diets were fed but with 2-2 $\mathrm{mm}$ pellet diet the use of multi-enzyme+phytase increased the albumin than the other groups. The cholesterol level was almost constant (an average $206 \mathrm{mg} / 100 \mathrm{ml}$ ) in the control groups and had a similar 
trend for phytase and multyenzime + phytase group when pellet diets were fed; however with mash diet, phytase reduced the cholesterol level than the other groups. The ALT levels were higher for mash and 3-3.5 mm pellet diet when broilers fed multi-enzyme+phytase, while the opposite happened for control and phytase groups. The AST/ALT ratio of broilers fed mash and 3-3.5 mm pellet diets was lower with multi-enzyme+phytase supplementation while the opposite occurred for 2-2 and 2-3 mm pellet diets.

\section{Blood haematology and immune indices:}

The blood profiles of broilers are shown in Table 5. Feeding 2-3 mm pellet diet significantly decreased haemoglobin, PCV, WBC and phagocytic activity and index compared to mash diet whereas an increasing pellet diameter to $3-3.5 \mathrm{~mm}$ resulted in similar haemoglobin and PCV in comparison to mash diet but in a higher value of RBC than mash and 2-2 $\mathrm{mm}$ pellet diet. Increasing pellet diameter to $3-3.5 \mathrm{~mm}$ significantly increased WBC and decreased PI in comparison to $2-3 \mathrm{~mm}$ pellet diet. Broilers fed $2-3 \mathrm{~mm}$ and $3-3.5 \mathrm{~mm}$ pellet had higher $(P<0.01)$ levels of lymphocyte and monocytes and lower $(P<0.01)$ values of heterophils and $\mathrm{H} / \mathrm{L}$ ratio than those on mash and $2-2 \mathrm{~mm}$ pellet diet. Increasing pellet diameter from $2-3 \mathrm{~mm}$ to $3-3.5 \mathrm{~mm}$ significantly decreased lymphocytes but increased heterophil level and $\mathrm{H} / \mathrm{L}$ ratio.

Phytase supplementation significantly increased RBC and PA but decreased PI compared to the control group. Phytase+multi-enzyme significantly increased RBC and WBC but decreased PI in comparison to the control group. Lymphocytes were significantly decreased in phytase supplemented group compared to other groups while monocytes increased. Multi-enzymes+phytase increased lymphocyte percentage but decreased monocytes in comparison to the phytase administered alone.

A significant interaction between form of diet and enzyme supplementation was shown on PCV, RBC, WBC, PI, lymphocytes, monocytes, heterophils and $\mathrm{H} / \mathrm{L}$ ratio. The PCV value was almost constant with mash diet; progressively increased from control to multi-enzyme+phytase with 3-3.5 mm pellet diet. The level of RBC was similar in control, phytase and multi-enzyme+phytase groups when mash diet was administered; with 2-3 $\mathrm{mm}$ and 3-3.5 $\mathrm{mm}$ pellet diets the RBC content progressively increased from mash to multi-enzyme+phytase diet while with $2-2 \mathrm{~mm}$ diet the RBC content measured in multienzyme+phytase groups was lower than that observed in the other groups. The great difference in WBC contents was observed in phytase supplemented groups as the cells were minimized to $2-2 \mathrm{~mm}$ and maximized to $3-3.5 \mathrm{~mm}$ diets. The phagocytic index showed a similar trend for phytase and multi-enzyme+phytase groups with higher values with mash and 2-3 mm pellet diets; the unsupplemented groups had lower values of PI with 2-3 mm and $3-3.5 \mathrm{~mm}$ pellet diets. The percentage of lymphocytes was similar among groups when 2-3 mm pellet diet was fed and was, respectively, minimized and maximized due to addition of phytase when mash and $2-2 \mathrm{~mm}$ or $3-3.5 \mathrm{~mm}$ pellet diets were fed. While for mash and 2-2 $\mathrm{mm}$ pellet diets the percentage of monocytes was slightly affected by different supplementations, the use of phytase gave higher levels of monocytes with 2-3 $\mathrm{mm}$ and 3-3.5 $\mathrm{mm}$ pellet diets. Higher values of heterophils were measured with phytase in mash and $2-2 \mathrm{~mm}$ pellet diets. The supplementation of multi-enzyme+phytase maximized the $\mathrm{H} / \mathrm{L}$ ratio in mash and 2-2 $\mathrm{mm}$ pellet diets; control and phytase groups gave higher values of $\mathrm{H} / \mathrm{L}$ ratio than multi-enzyme+phytase when $3-3.5 \mathrm{~mm}$ pellet diet was fed to broilers. 


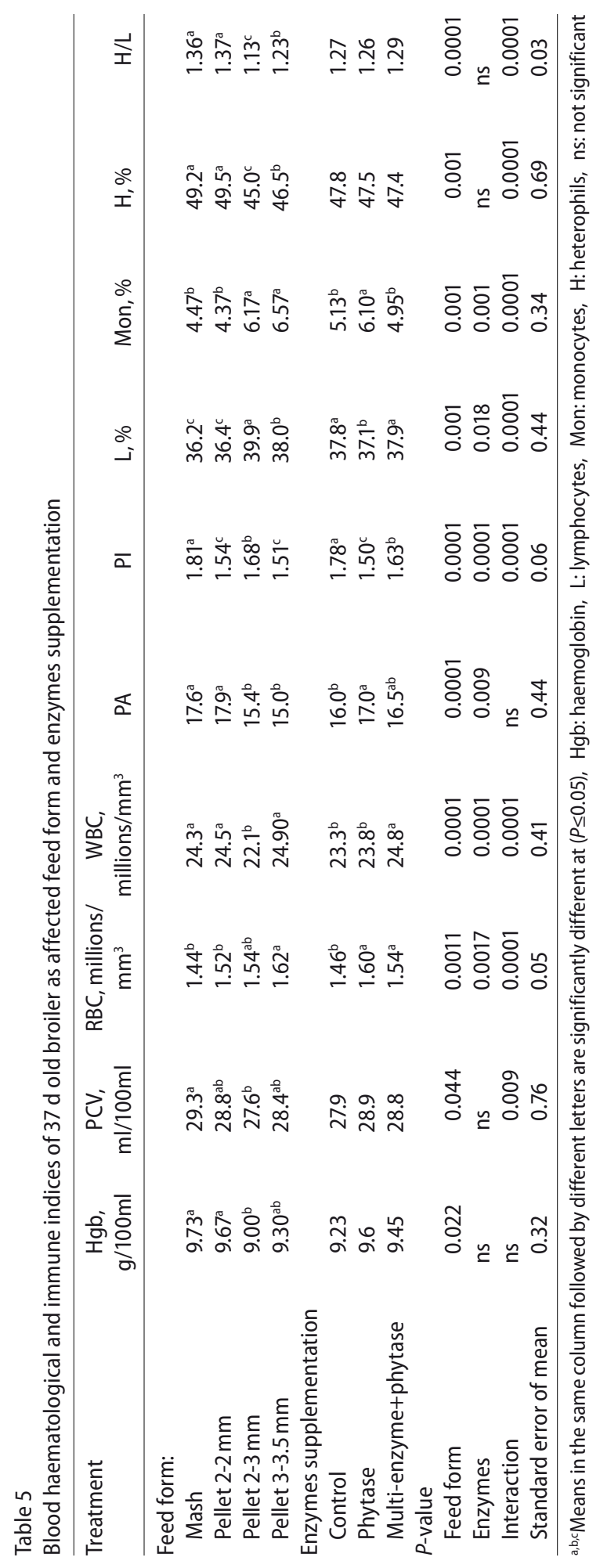




\section{Discussion}

\section{Effect of feed form}

The higher body weight at slaughter recorded with pellet diets was in line with other authors (Munt et al. 1995, Preston et al. 2000, Ghazi et al. 2012) who reported that the higher body weight was tied to a higher feed intake of broilers. The higher body weight also induced a higher weight of carcass with pellet diets. The decrease of gizzard percentage when pellet diet was fed is in line with the findings of Nyr et al. (1995) and Engberg et al. (2002). Also, according to Svihus et al. (2004) no effect of pellet size was recorded on gizzard percentage. The gizzard is a muscular organ that reduces particle size of ingested feeds and mixed them with digestive enzymes (Duke 1986). However, when pellet diets are fed, the particle size is tied to the particle size distribution after pellet dissolution in the crop: as a consequence, when the ingredients are finely grinded before pelleting, there is a lack of difference in particle size distribution after pelleting (Svihus et al. 2004). Regarding the other tracts of the digestive system, only the length of the caecum was reduced in comparison to the mash diet when birds fed $3-3.5 \mathrm{~mm}$ pellet diet and, even if not significant, the caecum length in birds fed the other two pellet diets was lower than that in the mash diet. This reduction is not easy to explain and, as limited to a specific gut compartment, it is probably tied to a redundancy of the digestive action in this tract. Also Amerah (2008) found a decrease of caecum length in poultry fed pellet diet in comparison to that fed a mash diet. The percentage of abdominal fat was significantly increased in the group fed $3-3.5 \mathrm{~mm}$ pellet diets in comparison to that in the mash group even if there is a tendency in abdominal fat percentage increase as the size of pellet increased. Sarvestani et al. (2006) also found an increase in abdominal fat percentage when broilers fed pellet instead of mash diet. However, the changes in abdominal fat percentages were not tied to a change in fat metabolism as the level of triglycerides was independent from feed form and cholesterol level modification were not in line with the changes of abdominal fat percentages.

The increase in abdominal fat percentage and in fat content of meat from broilers fed pellet diet 2-2 $\mathrm{mm}$ and 2-3 $\mathrm{mm}$ could be attributed to the decrease in energy expenditure for mechanical digestion and grinding in the gizzard. According to our results, Amerah et al. (2007c) reported that broilers fed pellet showed a decrease in the relative length of all parts of the digestive tract.

In literature, blood biochemical and haematological constituents of poultry were affected by genetic and environment factors (Attia et al. 2001, 2011a, b). Feed is one environmental factor that had greater influence on lipid and cholesterol metabolism. The present results demonstrated that feed form affected biochemical and haematological constituents of blood of broilers. The increase in plasma glucose and cholesterol in group fed 2-3 mm pellet diameter diet was concurred with increasing meat lipid.

Andi et al. (2011) found that difference in AST level between birds fed pelleted and mash diets were insignificant. In contrary, Corzo et al. (2012) reported that blood glucose was insignificantly affected by feed form, but total protein was significantly higher in broilers fed pelleted diet vs. those fed mash diet while albumin was found to be less in broilers fed mash than that in those fed pellet diet.

There were also negative changes in blood haematological traits (haemoglobin and PCV) with increasing pellet diameter to $2-3 \mathrm{~mm}$ although further increase to $3-3.5 \mathrm{~mm}$ restored 
blood haematological traits to the level of that of mash and $2-2 \mathrm{~mm}$ pellet diameter diet, indicating an improvement in the haematological traits. Similar trend was shown in WBC.

Our results showed that form of feeds significantly affected blood haematological traits and this depends on pellet diameter.

\section{Effect of enzyme supplementation}

An additive effect of multi-enzyme over phytase was shown in relative weight of dressing and total edible parts (3.8 vs. $1.22 \%$ ) and this concurred with a greater meat protein percentage (10.8 vs. $5.6 \%$ ) while decreasing meat moisture (4.4 vs. $2.8 \%$ ). This indicated that multienzymes showed synergic effects with phytase that resulted in an improvement in meat quality traits. These results are similar to those reported by Abd-Elsamee (2002), Attia et al. (2003a, b) and Salem et al. (2003) who concluded that the improvement in carcass yield due to enzyme supplementation is a reflection of the increase in nutrient availability for tissue growth.

Both phytase without or with multi-enzyme supplementations showed similar positive effects on total protein ( +7 and $+6 \%$, respectively), plasma glucose $(+8.1$ and $+7.7 \%$, respectively), triglycerides ( +2.22 and $+2.36 \%$, respectively) and $\mathrm{RBC}(+9.6$ and $+5.5 \%$, respectively). These changes in blood metabolism could be attributed to the increase in nutrient digestibility (Attia et al. 2003a,b, 2008) and suggests that phytase administered alone was sufficient to improve nutrient digestibility of broilers. Phytase alone decreased cholesterol by $7 \%$ and increased phagocytes activity by $6.1 \%$.

The lack of significant effect of enzymes on blood albumin, globulin, haemoglobin, PCV, basophils, heterophils, $\mathrm{H} / \mathrm{L}$ ratio and enzymes (AST and ALT) suggests that phytase or Avizyme had no adverse effect on plasma constituents and liver activity. In addition, as AST is a mitochondrial enzyme also found in peripheral tissues as muscles (Moniello et al. 2005, Bovera et al. 2007), also the muscular tropism seems to be unaffected by dietary treatments. These results are in general agreement with the results reported by Attia et al. (2001, 2003a,b), Qota et al. (2002) and El-Ghamry et al. (2005). They concluded that enzyme supplementation to broilers and ducks diets had no significant effect on plasma constituents. In addition, Ibrahim and Saleh (2005), Salem et al. (2008) and Elmenawey et al. (2010) reported that enzyme cocktail supplementation had no significant effect on plasma ALT concentration.

\section{Effect of the interaction}

There are several interactions between form of feed and enzyme supplementation on biochemical constituents of plasma (e.g. albumin, cholesterol, ALT and ALT/AST ratio); haematological traits (PCV, RBC, WBC, PI, lymphocyte, monocytes, heterophils, H/Lratio) and meat quality (moisture, fat, protein and meat tenderness). The effects were in general different for the different evaluated criteria and it is not easy to have a general conclusion about this. However, it is clear that the effect of enzyme depends on type of diet (pellet vs. mash). Phytase+multi-enzyme showed synergic effects on blood contents and meat quality of broilers based on pellet diameter as 2-3 mm pellet diameter diet showed greater effect than 2-2 $\mathrm{mm}$ pellet diet while increasing pellet diameter to $3-3.5 \mathrm{~mm}$ resulted in most cases in diminishing of response. An increase in welfare was shown when phytase+multi- 
enzyme was added to $2-3 \mathrm{~mm}$ and $3-3.5 \mathrm{~mm}$ pellet diameter diets. However, addition of phytase+multi-enzyme increased stress on broilers fed mash and 2-2 $\mathrm{mm}$ pellet diameter diet as indicated by increased $(\mathrm{H} / \mathrm{L}$ ) ratio may be due to boredom effect. Multi-enzymes+phytase showed greater effect (synergetic) on blood parameters and meat quality of broilers fed diet with 3-3.5 $\mathrm{mm}$ pellet diameter than 2-2 $\mathrm{mm}$ and 2-3 $\mathrm{mm}$ pellet diets. However, the lack of significant interaction between form of feed and enzyme supplementations on carcass characteristics and body organs and some blood parameters and meat quality indicated that either multi-enzyme+phytase or phytase alone supplementation to mash or pellet feeds is essential and the influence of enzymes is independent of type of feeds.

In general, pellet form of feed supplemented with multi-enzyme+phytase or phytase alone improved blood parameters and meat quality and multi-enzyme+phytase resulted in the highest percentages of dressing and total edible parts of broilers.

\section{References}

Abd El-Samee MO (2002) Effectof different levels of crude protein, sulpher amino acid, microbial phytase and their interaction on broiler chicks performance. Egypt Poult Sci J 22, 999-1021

Abudabos A (2010) Enzyme supplementation of corn-soybean meal diets improves performance in broiler chicken. Int J Poult Sci 9, 292-297

Abudabos AM (2012) Phytate phosphorus utilization and intestinal phytase activity in laying hens. Ital J Anim Sci 11, 41-46

Adeyemi OA, Eruvbetine D, Oguntona T, Dipeolu M, Agunbiade JA (2008) Feeding broiler chicken with diets containing whole cassava root meal fermented with rumen filtrate. Arch Zootec 57, 247-258

Agunbiade JA (2000) Utilisation of two varieties of full-fat and simulated soyabeans in meal and pelleted diets by broiler chickens. J Sci Food Agr 80, 1529-1537

Al-Harthi MA (2006) Impact of Supplemental Feed Enzymes, Condiments Mixture or Their Combination on Broiler Performance, Nutrients Digestibility and Plasma Constituents. Int J Poult Sci 5, 764-771

Amerah AM, Ravindran V, Lentle RG, Thomas DG (2007) Influence of particle size on the performance, digesta characteristics and energy utilisation of broilers fed maize and wheat based diets. Proc Aust Poult Sci Symp 19, 89-92

Amerah AM, Ravindran V (2008) Influence of method of whole-wheat feeding on the performance, digestive tract development and carcass traits of broiler chickens. Anim Feed Sci Technol 147, 326-339

Andi MA, Hashemi M, Ahmadi F (2011) Effects of Feed Type With/Without Nanosil on Cumulative Performance, Relative Organ Weight and Some Blood Parameters of Broilers. Global Vet 7, 605-609

AOAC (2004) Official methods of analysis. 18th ed., Association of Official Analytical Chemists, Washington, DC, USA

Attia YA, Abd El-Hamid AE, Qota EMA (2001) Effects of microbial phytase with or without cell-wall splitting enzymes on the performance of broilers fed suboptimum levels of dietary protein and metabolisable energy. Egypt Poult Sci J 21, 521-547

Attia YA, Qota EMA, Aggoor FAM, Kies AK (2003a) Value for rice bran, its maximal utilisation and its upgrading by phytase and other enzymes and diet-formulation based on available amino acids in the diet for broilers. Arch Geflugelk 67, 157-166

Attia YA (2003a) Performance, carcass characteristics, meat quality and plasma constituents of meat type drakes fed diets containing different levels of lysine with or without a microbial phytase. Arch Anim Nutr 66, 39-48

Attia YA (2003b) Responses of growth performance carcass characteristics, meat quality and plasma constituents of male Campbell ducks to dietary levels of methionine and phytase, and their interaction. Egypt Poult Sci J 23, 557-580 
Attia YA, Al-Harthi MA, El-Deek AA (2003b) Nutritive value of undehulled sunflower meal as affected by multienzyme supplementation to broiler diets. Arch Geflugelk 67, 97-106

Attia YA, Tag El-Din AE, Zeweil HS, Hussein AS, Qota ES, Arafat MA (2008) The Effect of Supplementation of Enzyme on Laying and Reproductive Performance in Japanese Quail Hens Fed Nigella Seed Meal. J Poult Sci 45, 110-115

Attia YA, Abd El-Hamid AE, Bovera F, El-Sayed MI (2009) Reproductive and productive performance of rabbit does submitted to an oral glucose supplementation. Animal 3, 1401-1407

Attia YA, Al-Hanoun A, Bovera F (2011a) Effect of different levels of bee pollen on performance and blood profile of New Zealand White bucks and growth performance of their offspring during summer and winter months. J Anim Physiol Anim Nutr 95, 17-26

Attia YA, Al-Hanoun A, Tag El-Din AE, Bovera F, Shewika YE (2011b) Effect of bee pollen levels on productive, reproductive and blood traits of NZW rabbits. J Anim Physiol Anim Nutr 95, 294-303

Attia YA, El-Tahawy WS, Abd Al-Hamid AE, Hassan SS, Nizza A, El-Kelaway MI (2012) Effect of phytase with or without multienzyme supplementation on performance and nutrient digestibility of young broiler chicks fed mash or crumble diets. Ital J Anim Sci 11, 303-308

Attia YA, El-Hanoun AM, Bovera F, Monastra G, El-Tahawy WS, Habiba HI (2013) Growth performance, carcass quality, biochemical and haematological traits and immune response of growing rabbits as affected by different growth promoters. J Anim Physiol Anim Nutr 98, 128-139

Bovera F, Moniello G, De Riu N, Di Meo C, Pinna W, Nizza A (2007) Effect of diet on the metabolic profile of ostriches (Struthio camelus var. domesticus). Trop Anim Health Prod 39, 265-270

Choct M (2006) Enzymes for the feed industry: past, present and future. Worlds Poult Sci J 62, 5-16

Corzo A, Mejia L, McDaniel CD, Moritz JS (2012) Interactive effects of feed form and dietary lysine on growth responses of commercial broiler chicks. J Appl Poult Res 21, 70-78

Duke GE (1986) Alimentary canal: Secretion and digestion, special digestive functions, and absorption. In: Sturkie PD (ed.) Avian Physiology, 4th ed., New York, NJ, USA, 269-288

Durrani FR, Ismail M, Amjad M, Suhail SM, Chand N (2006) Effect of different levels of feed added turmeric (Curcuma longa) on the performance of broiler chicks. J Agric Biol Sci 1, 9-11

El-Ghamry AA, Al-Harthi MA, Attia YA (2005) Possibility to improve rice polishing utilisation in broiler diets by enzymes or dietary formulation based on digestible amino acids. Arch Geflugelk 69, 49-56

Elmenawey MA, Ali AHR, Galal MAA, Stino FKR (2010) Influence of enzyme supplementation in the diet on egg production, egg quality and some blood constituents of Matrouh hens. Egypt Poult Sci J 30, 661-678

Engberg RM, Hedemann MS, Jensen BB (2002) The influence of grinding and pelleting of feed on the microbial composition and activity in the digestive tract of broiler chickens. Br Poult Sci 43, 569-579

Hassan MM, El-Sheikh SEM (2010) Effect of physical form of diets on the performance of ducks. Egypt Poult Sci J 30, 989-1002

Husani SA, Deartherage FB, Kunkle LE (1950) Studies on meat: 11 observations on relation of biochemical factors to change in tenderness. Feed Technol 4, 366-369

Ibrahim KA, Saleh ES (2005) Response of male broiler chicks to skip a day feeding Programs. Egypt Poult Sci J 25, 351-37

Kidd MT, Morgan GW, Price CJ, Welch PA, Fontana EA (2001) Enzyme Supplementation to Corn and Soybean Meal Diets for Broilers. J Appl Poult Res 10, 65-70

Moniello G, Bovera F, Solinas IL, Piccolo G, Pinna W, Nizza A (2005) Effect of age and blood collection site on the metabolic profile of ostriches: short communication. South Afr J Anim Sci 35, 267-271

Munt RHC, Dingle JG, Sumpa MG (1995) Growth, carcass composition and profitability of meat chickens given pellets, mash or free-choice diet. Br Poult Sci 36, 277-284

NRC (1994) Nutrient requirements of poultry. 9th rev. version, National Research Council, Washington, DC, USA

Nir I, Twina Y, Grossman E, Nitsan Z (1994) Quantitative effects of pelleting on performance, gastrointestinal tract and behaviour of meat-type chickens. Br Poult Sci 35, 589-602 
Nir I, Hillel R, Ptichi I, Shefet G (1995) Effect of Particle Size on Performance. 3. Grinding Pelleting Interactions. Poult Sci 74, 771-783

Preston CM, McCracken KJ, McAllister A (2000) Effect of diet form and enzyme supplementation on growth, efficiency and energy utilisation of wheat-based diets for broilers. Br Poult Sci 41, 324-331

Qota EMA, Al-Ghamry AA, El-Mallah GM (2002) Nutritive value of soaked linseed cake as affected by phytase, Biogen supplementation or formulating diets based on available amino acid on broiler performance. Egypt Poult Sci J 22, 461-475

Salem AA, El Anwer EMM, Abo-Eita EM, Namra MMM (2008) Productive and physiological performance of golden Montazah male chickens as affected by feed restriction and anizyme supplementation. Egypt Poult Sci J 28, 1137-1164

Salem FM, El-Alaily HA, El-Medany NM, Abd El-Galil K (2003) Improving phosphorus utilization in broiler chick diets to minimize phosphorus pollution. Egypt Poult Sci J 23, 201-218

Sarvestani TS, Dabiri N, Agah MJ, Norollahi H (2006) Effect of Pellet and Mash Diets Associated with Biozyme Enzyme on Broilers Performance. Int J Poult Sci 5, 485-490

Shirzadi H, Moravej H, Shivazad M (2009) Comparison of the effects of different kinds of NSP enzymes on the performance, water intake, litter moisture and jejunal digesta viscosity of broilers fed barley-based diet. J Food Agric Env 7, 615-619

SAS (2002) SAS/STAT software, version 9. SAS Institute, Inc., Cary, NC, USA

Svihus B, Kløvstad KH, Perez V, Zimonja O, Sahlström S, Schüller RB, Jeksrud WK, Prestløkken E (2004) Physical and nutritional effects of pelleting of broiler chicken diets made from wheat ground to different coarsenesses by the use of roller mill and hammer mill. Anim Feed Sci Technol 117, 281-293

Volovinskaia VP, Kelman BY (1962) Modification of the water holding capacity method of meat. Feed Ind 11, 80-82

Zohair GAM, Al-Maktari GA, Amer MM (2012) A Comparative Effect of Mash and Pellet Feed on Broiler Performance and Ascites at High Altitude (Field Study). Global Vet 9, 154-159 